\title{
GEOCHEMICAL INVESTIGATION OF AQUIFER POLLUTION FROM WASTE MANAGEMENT. THE CASE OF KOMOTINI LANDFILL (GREECE)
}

\author{
Raco B. ${ }^{1}$, Dotsika E. ${ }^{2}$, Psomiadis D. ${ }^{2}$, Doveri M. ${ }^{1}$, Lelli M. ${ }^{1}$, Zisi N. ${ }^{2}$, \\ Papakonstantinou K. ${ }^{3}$ and Lazaridis A. ${ }^{4}$ \\ ${ }^{1}$ Institute of Geosciences and Earth Resources,Via G. Moruzzi 1, 56124 Pisa, Italy, b.raco@igg.cnrit, \\ doveri@igg.cnr.it,m.lelli@igg.cnr.it \\ ${ }^{2}$ Stable Isotope Unit, Institute of Materials Science, NCSR Demokritos, Agia Paraskevi Attiki, Greece, edot- \\ sika@ims.demokritos.gr,dapsom@ims.demokritos.gr,nzissi@ims.demokritos.gr \\ ${ }^{3}$ Georesources Technology S.A., Perigiali, Kavala, Greece, cmp@georesources.gr \\ ${ }^{4}$ Greek Ministry of National Education and Religious Affairs, Andrea Papandreou 37, \\ Marousi 15180 Greece
}

\begin{abstract}
According to European legislation, environmental control and monitoring of landfills has become of crucial importance. This study includes a thorough geochemical approach aiming to evaluate the environmental impact of the landfill of Komotini, N. Greece. Samples of waters were taken from inside the working landfill as well as from the area of the neighbouring old landfill. The waters were analyzed chemically (major elements and heavy metals) and isotopically $\left(D\right.$ and $\left.{ }^{18} \mathrm{O}\right)$. Also, biogas flow was measured and the ratio $\mathrm{CH}_{4} / \mathrm{CO}_{2}$. Based on the geomorphological, hydrogeological and land use data of the area, we proceeded to analyses of waters both from the area of the landfill and from the wider region (drainage basin). The obtained results were used to construct digital maps (GIS) in order to determine the special dispersion of the polluted aquifers. The biogas flow in the old and new garbage burial sites was measured by accumulation chamber device for methane and carbon dioxide ratio determination. The obtained results show an important agent of pollution in the water samples downstream from the landfill and in a distance more than $2 \mathrm{~km}$, along the dispersion of the leachate. The land use of the area was taken into account to evaluate the importance and the criticality of the situation.
\end{abstract}

Key words: aquifer pollution, waste, landfill, Komotini, Greece.

\section{Introduction}

Integrated management of urban waste has become one of the top priorities of the national and especially of the European environmental policy, which has adapted the basic principles of sustainable development: reduction, reuse, recycle and safe disposal. Therefore, there has been commenced an intense effort of closing and restoring old landfills and installing new ones, which will correspond to modern advanced specifications.

Landfill monitoring is a vital chapter for detecting and precluding possible environmental impacts during both operation and restoral. In Greece, the subject of monitoring and supervising of landfills remains still a side issue in planning and installing of such a project, rendering the present frame- 
work in total inconsistence with the relative European directives.

Isotopic composition of elements is a powerful and refined instrument to obtain information about origin and history of the examined chemical species. Light elements isotopic composition in particular, being affected by great relative mass differences among the isotopes of a same element, offers many possible applications in monitoring, also because of the sensible fractioning occurring at environmental temperatures (Clark and Fritz, 1997). This kind of analysis has become an integrating essential part in the study of environmental impact of landfills, being able to provide information and evaluation instruments not obtainable with other methods (see Hackley et al., 1996; Doveri et al., 2007).

\section{Area of study}

The study site is the landfills of Komotini (Thrace, N. Greece), including the old restored one (OL) and the new operating landfill (NL) (Fig. 1, map). NL began its operation in 1994, substituting OL in the vicinity. OL was set out of operation due to several negative effects in the region and also after reaching its operational maximum. NL is located NW of Stylario village, approximately $7 \mathrm{~km}$ NE of the city of Komotini, at $150 \mathrm{~m}$ above sea level. The total surface of NL reaches up to $113000 \mathrm{~m}^{2}$. OL is approximately $6,5 \mathrm{~km}$ eastward of Komotini, near village Kalhas, at $100 \mathrm{~m}$ above sea level. Its surface is $57000 \mathrm{~m}^{2}$ and its subbasin exits to SSW, covered by bushy vegetation. The study area belongs to the graben of Xanthi - Komotini. NL is at a medium (old) level of morphological relief (the relief is characterized by hills and alluvial sediments at the lower altitudes). The slopes are relatively small and vary between $2,6-16 \%$. The eastern part of the region of the landfills is marked by small hills and wide shallow basins. There are some eroding phenomena by the local streams, with a quite low activity though. The area belongs to the drainage basin of river Fyliris, which is considered to be the most important in the region of the Xanthi - Komotini plain. To the north, it is parted from the older metamorphic bedrock by a fault (NE dir), to the SW it is parted from the Tertiary basin of Nestos-Prinos by the tectonic horn of Avdira and to the NE it borders the Tertiary basin of Alexandroupolis. Mean annual outflow of the Fyliris river basin is $305 \cdot 10^{6} \mathrm{~m}^{3}$ or $9,67 \mathrm{~m}^{3} / \mathrm{s}$, which equals to rainfall of $204,7 \mathrm{~mm}$. Mean annual underground flow of Fyliris is $2,73 \mathrm{~m}^{3} / \mathrm{s}$ and equals to rainfall of $57,7 \mathrm{~mm}$. Evaporation of the basin of Fyliris river during $1980-81$ was $479,7 \mathrm{~mm}$. The active percolation during the same year was $63 \mathrm{~mm}$. Fyliris river, after exiting the chrystalline schist, covers a distance of $25-35 \mathrm{~km}$ on the Holocene sediments. The landfill region is on the Pleio-Pleistocene sediments. Inside the rough materials, local aquifers appear. Deep and rich aquifers are not excluded. In the vicinity of the landfill a poor shallow aquifer is formed. Its development takes place in the layers of sand and gravels, which covers the first 6-8 meters depth at the north. At the south, the aquifer is developed again in the layers of sand and gravels up to 11 meters depth, where it stops on the clay strata. Possibly, there is a deeper and richer aquifer, but the contact of the two is considered very unlikely because of the clay-strata.

\section{Methods}

The integrated approach included a) chemical and isotopic analysis of leachate in the landfill body, with the aim of indicating eventual differences between OL and NL and to characterize the leachate from external waters, b) chemical and isotopic analysis of piezometers and some external wells to point out an eventual contamination or a lack of leachate containment, c) a measurements-survey of diffused biogas, aimed at evaluating the global amount of biogas released from soil and estimating the efficiency of the covering and d) chemical analysis of biogas.

Water samples were analyzed as follows: cations and heavy metals by optical ICP-OES, anions by liquid chromatography, ammonia by a specific electrode and COD through spectrometry. Oxygen 


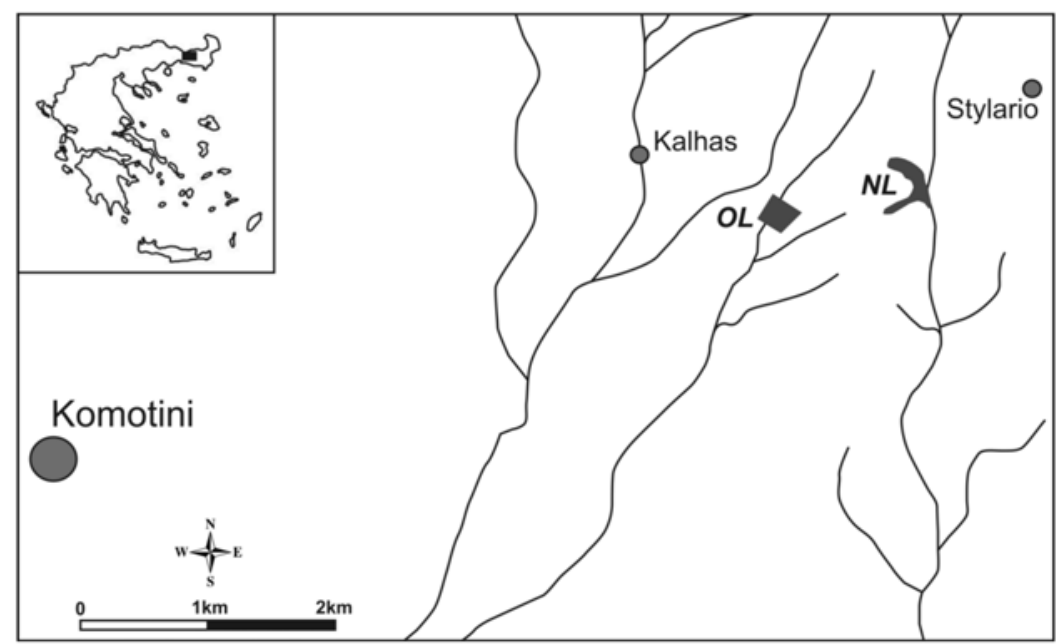

Fig. 1: Simplified map of the study area showing the main urban sites. NL: New landfill; OL: Old landfill. The region south of the two landfills is entirely used for agricultural activities.

and Hydrogen isotopic compositions were analyzed through mass spectrometry respectively of $\mathrm{CO}_{2}$, obtained by equilibration with the water itself, and of $\mathrm{H}_{2}$, obtained by reaction to metallic zinc at $400^{\circ} \mathrm{C}$. Isotopic analyses have been carried out according to the usual preparation and measurement techniques with mass spectrometry for $\delta^{2} \mathrm{H}, \delta^{13} \mathrm{C}$ and $\delta^{18} \mathrm{O}$ and with liquid scintillation for ${ }^{3} \mathrm{H}$. All results have been reported with the usual $\delta \%$ unit (difference in parts per 0.1 per cent between the measured isotopic correlation, for example ${ }^{18} \mathrm{O} /{ }^{16} \mathrm{O}$, in the sample and the same rate in a international agreed standard) vs. the SMOW standard (average isotopic composition of oceanic waters) for hydrogen and oxygen stable isotopes in waters, vs. PDB (composition of a sea biogenic carbonate as reference) for carbon.

The biogas flux measurements were carried out with the stationary method of accumulation chamber (Witkamp, 1969; Kucera and Kirkham, 1971; Kanemasu et al., 1974; Parkinson, 1981, Tonani and Miele, 1991; Chiodini et al., 1996; Chiodini et al., 1998) considering the lower weather dependence conditions indicated by Trégourès et al. (1999). This method allows to measure the increase of concentration of a given gas specie inside a sealed chamber, open only on the bottom, in touch with the ground; a non stationary version has been used to measure the diffused gas emissions in landfills (Cossu et al., 1997).

A detailed description of this instrumentation has been reported by Chiodini et al. $(1996,1998)$ and in Raco et al. (2005). In Raco et al. (2005), also the influence of weather parameters, especially of atmospheric pressure, was considered. For what chemical analysis of gas are concerned, widely standardized methodologies have been used; in particular gas chromatography for $\mathrm{CO}_{2}, \mathrm{CH}_{4}, \mathrm{O}_{2}+$ $\mathrm{Ar}, \mathrm{N}_{2}$ concentrations.

Samples collected by sucking with syringe by pass, in pyrex containers: 1) in OL, in three different spots, by a metallic tube with holes, which was dipped $20 \mathrm{~cm}$ in the permeable covering inside the collectors (chimneys) of degassing, 2) in NL, using again the metallic tube, dipped $50 \mathrm{~cm}$ in the temporary covering of the garbage at the active part of the landfill.

$108 \mathrm{CO}_{2}$ and $\mathrm{CH}_{4}$ soil flux measurements were made, covering the whole area of NL, with the ex- 
Table 1. Physicochemical characteristics of samples.

\begin{tabular}{|c|c|c|c|c|c|c|c|c|c|}
\hline Sample & North & East & Type & $\begin{array}{c}\text { Depth } \\
(\boldsymbol{m})\end{array}$ & Date & $\begin{array}{c}\boldsymbol{T} \\
\left({ }^{\circ} \boldsymbol{C}\right)\end{array}$ & $\boldsymbol{p H}$ & $\begin{array}{c}\text { Cond } \\
\boldsymbol{\mu S / c m} \\
\left(\mathbf{2 0} \mathbf{C}^{\circ}\right.\end{array}$ & $\begin{array}{c}\mathbf{m e q}^{\prime l} \\
\boldsymbol{H C O}_{3}\end{array}$ \\
\hline GR1 & 41,1391 & 25,4886 & borehole & 25,0 & $19 / 09 / 2007$ & 21 & 6,85 & 1786 & 8 \\
\hline perc & 41,1372 & 25,4922 & leachate & & $19 / 09 / 2007$ & 28 & 7,53 & 67100 & \\
\hline GR2 & 41,0938 & 25,4932 & borehole & 85,0 & $19 / 09 / 2007$ & 21,1 & 7,04 & 1880 & 8,5 \\
\hline GR3 & 41,1439 & 25,4907 & well & 4,4 & $19 / 09 / 2007$ & 21,6 & 7,27 & 1926 & 10,6 \\
\hline GR4 & 41,1279 & 25,4924 & spring & & $19 / 09 / 2007$ & 20 & 6,57 & 1197 & 7 \\
\hline GR5 & 41,1279 & 25,4926 & $\begin{array}{c}\text { open trench } \\
\text { surface }\end{array}$ & 3,0 & $19 / 09 / 2007$ & 19,5 & 7,16 & 1098 & 6,5 \\
\hline GR6 & 41,1240 & 25,4936 & well & 5,6 & $19 / 09 / 2007$ & 20 & 6,86 & 1630 & 8,7 \\
\hline GR7 & 41,1413 & 25,4921 & well & 4,7 & $20 / 09 / 2007$ & 19,5 & 7,29 & 1418 & 7 \\
\hline GR8 & 41,1384 & 25,4809 & well & 8,9 & $20 / 09 / 2007$ & 18 & 7,37 & 2130 & 6,4 \\
\hline GR9 & 41,1302 & 25,4733 & well & 5,9 & $20 / 09 / 2007$ & 19,5 & 6,7 & 4090 & 12,2 \\
\hline GR10 & 41,1282 & 25,4922 & open trench & & $20 / 09 / 2007$ & 19,9 & 7,7 & 9000 & \\
\hline
\end{tabular}

ception of the cultivated area. The covered surface was calculated to be around $10200 \mathrm{~m}^{2}$, the dimension of sampling network was of $10 \mathrm{~m} \times 10 \mathrm{~m}$ and the location of sampling spots is shown in figure 2. Several measurements took place in OL, which were located on a matrix with cell $20 \mathrm{~m}$ x $20 \mathrm{~m}$. We also measured at the inclined perimeter of the landfill. The rest part was covered sparsely. There were no fluxes in the region, except from the degassing tubes (chimneys).

\section{Data analysis}

\subsection{Chemistry of waters}

The water samples are shown in table 1, which includes also a general description of the sampling sites and of the parameters measured during the campaign. Measurements took place four times during the year for the general chemical parameters ( $\mathrm{T}, \mathrm{pH}$, Cond) and two times for the basic chemical elements. Based on the fact that the measured values where similar between the periods of measurement, GIS maps and data process were structured on one period data set (19/09/2007). Also, values of heavy metal composition of the water samples were measured $(\mathrm{Cr}, \mathrm{Ni}, \mathrm{B}, \mathrm{Hg}$, As were measured at the laboratory). A first glance at table 1 and in particular at the measured data set shows a range of conductivity included between 1000 and $2000 \mu$ S, typical of surface water wells in cultivated area, with the only exception of well GR9 down the old landfill and of GR10, which appeared to be contaminated by leachate also at the sight. Leachate shows a value of $67100 \mu \mathrm{S} / \mathrm{cm}$, this value is extremely high if compared to that of other similar measurements shown by literature and suggests that we are in presence of real leachate, even if this one was sampled under the form of overflowing, immediately down the area of waste disposal and not far from subsuperficial water flows.

The first step for the interpretation of these analyses is made by a hydrochemical classification of waters here obtained with the well known Langelier-Ludwig (LL) diagrams. 

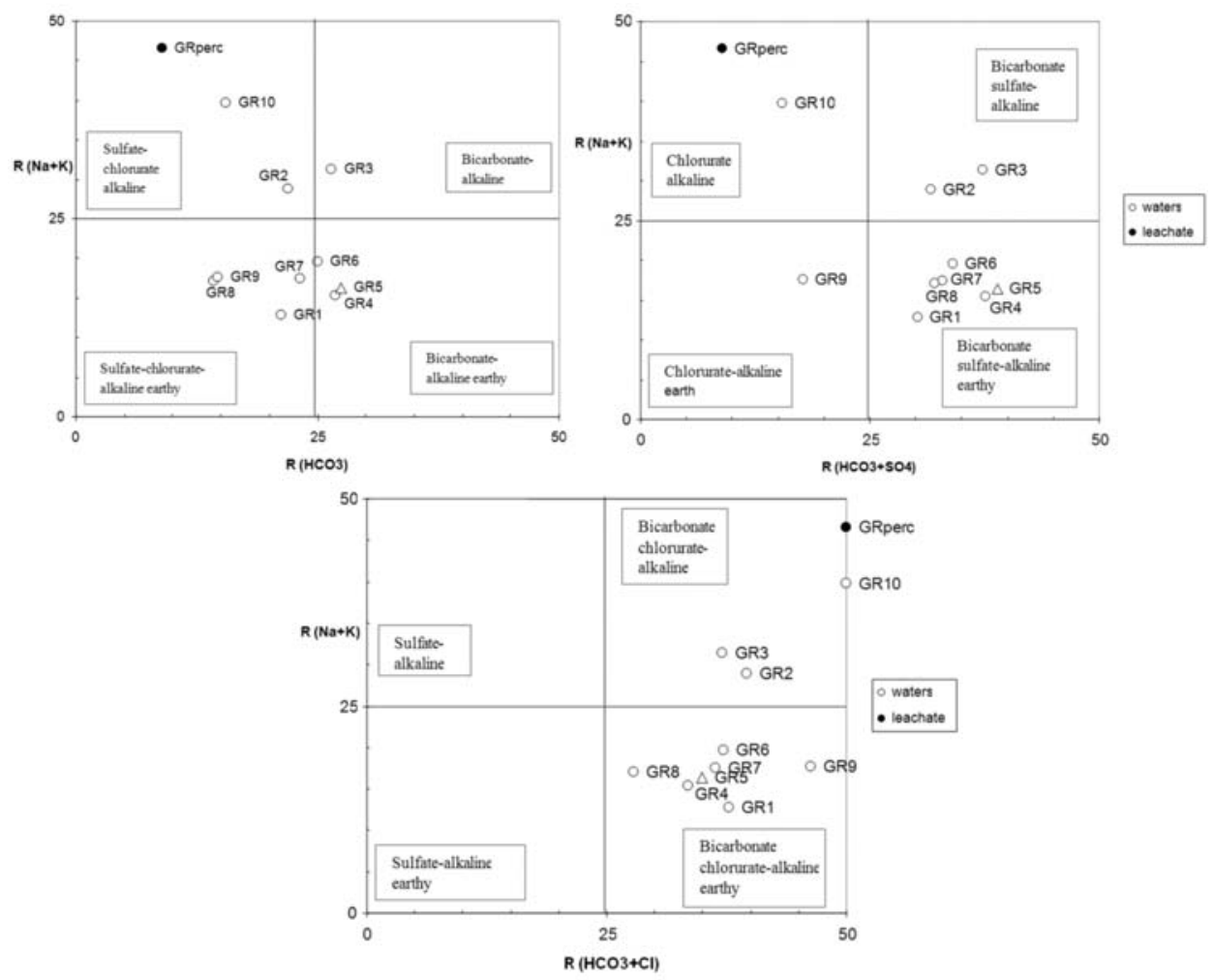

Fig. 2: $\mathrm{LL}_{(\mathrm{HCO} 3)}$ diagrams.

The chemical composition of a water sample is shown in LL diagram, using Ri reaction values, which have been calculated from the concentration of their major constituents (cations and anions) expressed in eq/l (or meq/l). By keeping the cations groups constant, three LL diagrams could be made, $\mathrm{LL}_{\mathrm{HCO} 3}$, $\mathrm{LL}_{\mathrm{Cl}}$ and $\mathrm{LL}_{\mathrm{SO} 4}$, which have bicarbonate, chlorurate and sulfate as respective isolated ions. $\mathrm{LL}_{\mathrm{HCO} 3}$ diagram allows distinguishing waters with bicarbonate as main ion from the sulfate-chlorurated ones. $\mathrm{LL}_{\mathrm{Cl}}$ and $\mathrm{LL}_{\mathrm{SO} 4}$ diagrams will allow identifying within the group of sulfate-chlorurated waters those with a dominant component of sulfate or chloride. From LL diagrams in figure 2 it can be observed that eight samples have a sulfate chlorurated alkaline-earthy composition, GR2 and GR3 samples have an alkaline dominant and GR9 and GR10 are respectively chlorurated alkaline-earthy and chlorurated-alkaline. The leachate sample shows an evident chlorurated-alkaline composition.

The always present correlation between the above parameters, in case of samples with visible (GR10) or possible (GR9) contamination from leachate and leachate itself is very clear and shows the tracing reliability of such parameters in this particular geological context, where the content of $\mathrm{Cl}$ and bicarbonate is not particularly high. It is important to notice that this observation is not trivial as it may appear. In fact, geological formations rich in chloride and/or bicarbonate are obviously quite common and especially their content in chloride can easily reach very high peaks in slow circulation systems or in those affected by sea intrusion or geothermal contribution.

\subsection{Isotopic composition of waters}




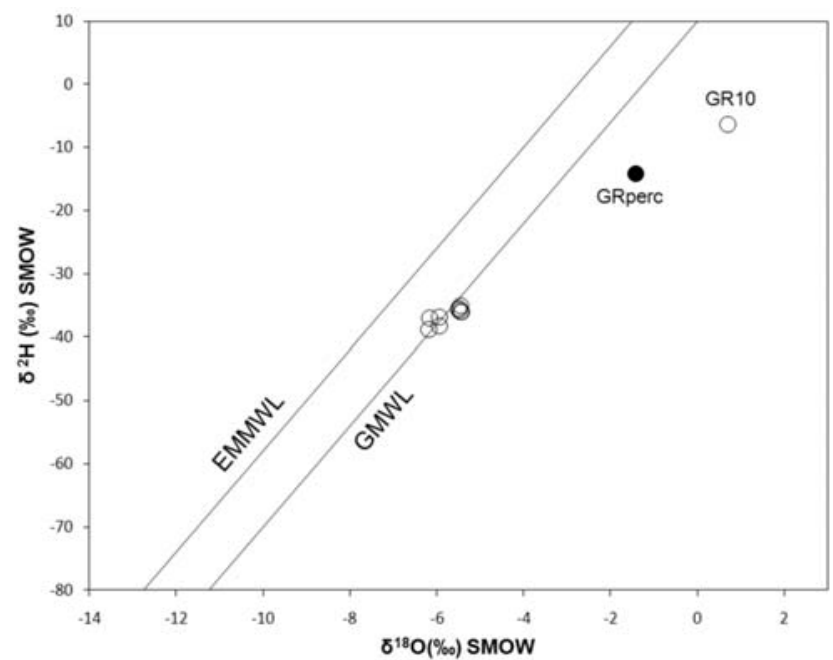

Fig. 3: $\delta \mathrm{D}$ versus $\delta^{18} \mathrm{O}$ diagram.

Data referring to isotopic composition of waters have been interpreted with the classical $\delta^{2} \mathrm{H} \%$ o versus $\delta^{18} \mathrm{O} \%$ diagram, shown in figure 3. In the same diagram are shown, as usual, the lines corresponding to the points where average isotopic compositions of waters with direct meteoric origin can be localised (in details, the "world meteoric line" and that originating from data on central Mediterranean rain (Gonfiantini, 1983; IAEA, 2007).

The results concerning sampled waters appears to be in agreement with those of the world meteoric line and with the results of some measurements on regional waters carried out during a previous study (Grassi et al., 1996). This area, compared to others at higher altitude or affected by mountainous barriers, produces isotopic compositions more aligned along the world meteoric line rather than on the Mediterranean one. The deepest sample (GR2, -90m) shows slightly lower isotopic values but similar results can be observed also in GR1 (-30m) and in the more superficial well GR9 (-6,3m).

The samples GRperc (leachate) and GR10 (small open-cut sinking in the torrent which morphologically drains the waste disposal plant with evident presence of leachate), show an isotopic composition typical of local meteoric waters subject to a broad process of evaporation (IAEA, 1981). In the leachate sample (GRperc) there is no trace of $\delta^{2} \mathrm{H} \%$ shift towards values of higher isotopic composition and located, in the above quoted diagram, over the meteoric waters line, a shift which often characterize landfill leachate samples after the isotopic exchange with methane inside biogas.

Isotopic composition of dissolved inorganic carbon in water of GR1, 2, 3, 4, 5, 6, 7, 8 samples shows $\delta^{13} \mathrm{C}(\mathrm{DIC}) \%$ values typical of superficial water streams in cultivated areas, resulting from the mixing of carbon from organic material oxidation, up to $-30 \%$, with carbon from atmospheric $\mathrm{CO}_{2}$ or carbonatic mineral dissolution; they both originate a $\delta^{13} \mathrm{C}$ (DIC) close to $0 \%$ (Clark and Fritz, 1997) (Fig. 4). A minor superficial component is in agreement with the slightly higher value of the deep well GR2. GRperc sample is strongly enriched in ${ }^{13} \mathrm{C}$ due to the methanegenesis generating methane with low $\delta^{13} \mathrm{C}$ values and consequent carbon isotopic enrichment in the coexisting $\mathrm{CO}_{2}$ and therefore in the originating DIC; the same can be observed in GR10 which shows a large component of leachate. A separate consideration must be made for GR9 sample. In this superficial well down the old remediate landfill, the measured value $(+3.3 \%)$ is hardly justified in the case of a superficial well 

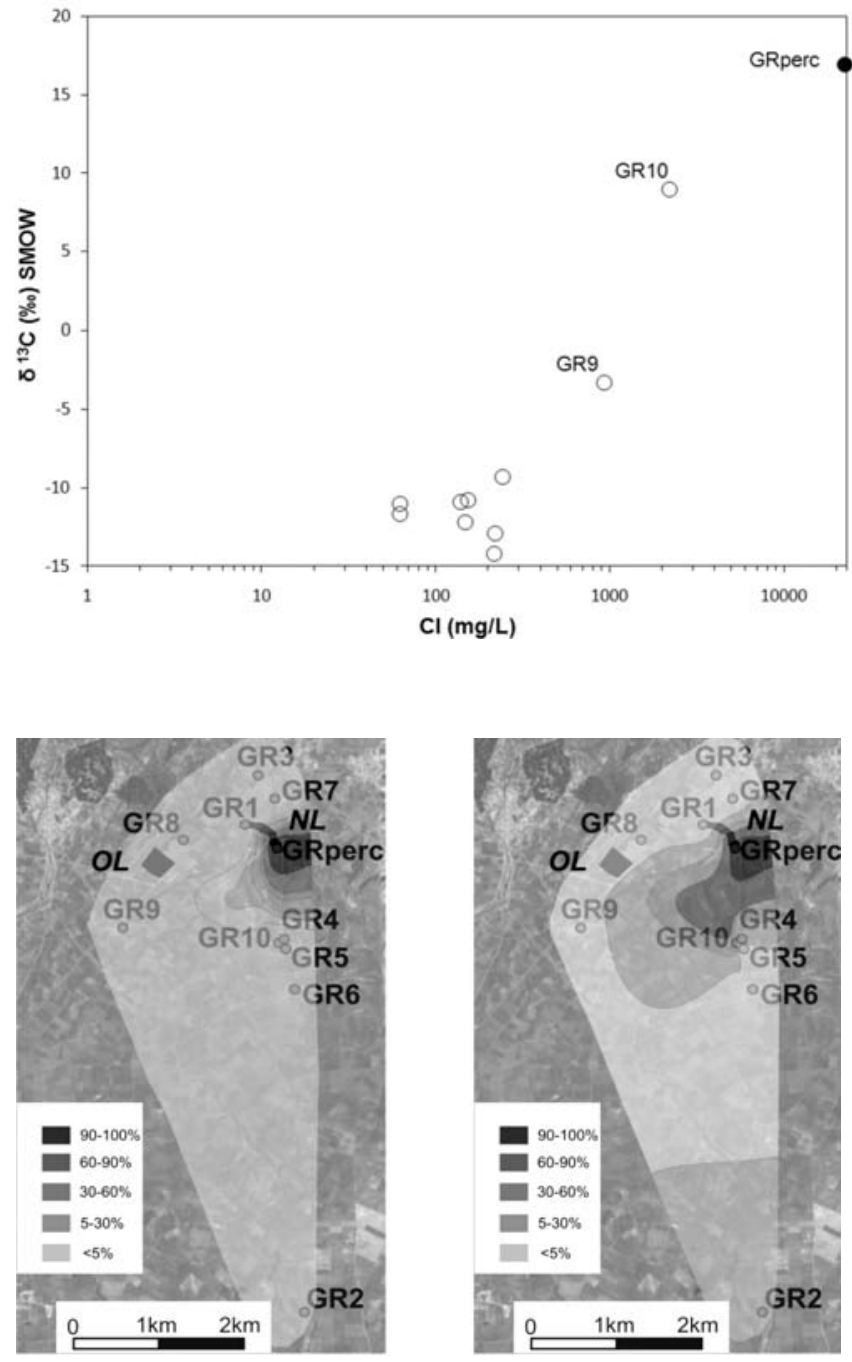

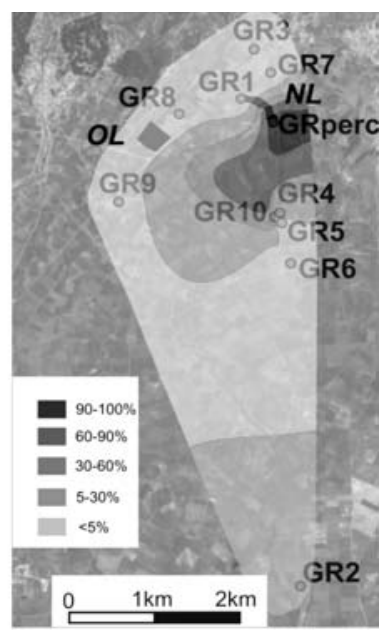

Fig. 4: $\delta^{13} \mathrm{C}$ versus $\mathrm{Cl}$ diagram. The $\mathrm{Cl}$ content is reported in logarithmic scale.
Fig. 5: Percentage of leachate contamination in waters of the region, based on Cl- (left) and B-(right) composition.

from a cultivated area, even according to what was measured in the other investigated wells. An acceptable hypothesis interprets this value as a trace of leachate coming from the old landfill.

\subsection{Contamination}

Based on GIS analysis, maps of the water contamination percentage regarding the $\mathrm{Cl}$ and $\mathrm{B}$ composition from leachate have been created (Fig. 5).

The study of these maps shows the percentage of participation of the polluted liquid (leachate) in the waters of the region. The contamination level of groundwaters is relatively low $(<5 \%$ leachate intrusion) in distances over $1 \mathrm{~km}$. In the region around the leachate sampling site (circle of $300 \mathrm{~m}$ radius) the contamination percentage increases rapidly, reaching dangerous values. Sample GR2 shows an increased level of contamination regarding some of B. The chemical measurements of the water samples render them either in the suggested limits for drinking water (EU standards, Bouwer, 1978), 


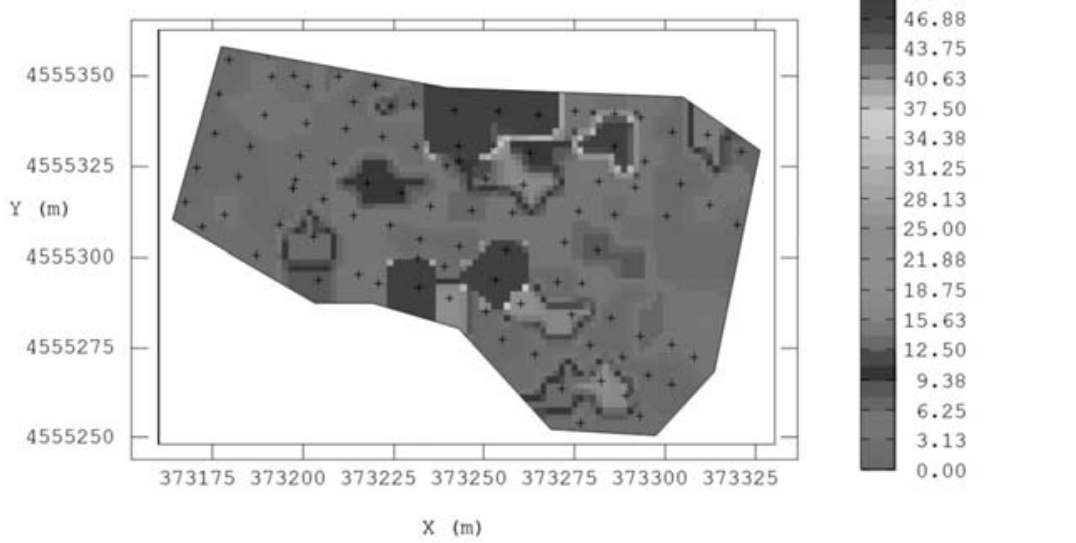

Fig. 6: Isoflux map.

(GR1, GR3, GR4, GR5, GR6, GR7, GR8) or quite above the acceptable limits (GR2, GR9, GR10, GRperc). Sample GR9 has relatively high concentrations of the selected elements, a fact that can be explained by a possible leachate contamination from the old landfill rather than by water use in the area (i.e. agriculture).

\subsection{Biogas}

In order to calculate the total flux of soil biogas, Sinclair's $(1974 ; 1991)$ methodology and Sichel's (1966) calculations were used. Isoflux maps were produced by processing all biogas flux rate data with ISATIS, a program developed by Fontembleu School, which uses the Kriging method to extrapolate values (Clark, 1979 and relative references). Being the distribution of log-normal type the log-normal kriging was used, to build the map shown in figure 6.

\section{Conclusions-Results}

The procedure here described, the obtained results and their interpretation must be considered as an applicative test, already able to reveal some useful information about the environmental state of the site and also aiming to acknowledge and develop the proposed integrated approach. The chemical and isotopic composition of the leachate is in agreement with literature, except two notable differences. The first, chemical one, is that the dominant anion is the chloride, while typically the leachate is dominated by bicarbonate of ammonium; the second, isotopic one, is that the content in tritium was estimated low, showing possible dilutions of the sample. Both these observations are well explained by the young age of the landfill. An extremely important observation from the environmental point of view is the fact that the waters of the well GR9, located downstream of the old site, show a contamination from the leachate, based on the chemical parameters than isotopic. The contamination of the torrent that drains the new landfill (GR10) is obvious at any part of it. However the characterization of the leachate shows the need of a future monitoring by means of appropriate methods.

The emission of biogas in NL of Komotini, estimated as the sum of $\mathrm{CO}_{2}$ and $\mathrm{CH}_{4}$, resulted to 109 $(168 \div 85 \mathrm{Nm} 3 / \mathrm{h})$ with a specific flow of about $11 \mathrm{Nl} / \mathrm{m} 2$, a value rather high, but typical of landfill sites with no proper installations for the capture of the biogas. OL, closed and covered, has a low 
emission, measurable only in the north slope while an important flow is present, as expected, in the chimneys of degassing.

\section{Acknowledgments}

The authors would like to thank the employees of the Municipality of Komotini as well as the workers in the landfills for their help during data gathering and field works.

\section{References}

Chiodini, G., Frondini, F., Raco, B., 1996. Diffuse emission of CO2 from the Fossa crater, Vulacno Island (Italy). Bull. Volcanol., 58, 41-50.

Chiodini, G., Cioni, R., Guidi, M., Marini, L., Raco, B., 1998. Soil CO2 flux measurements in volcanic and geothermal areas. Applied Geochemistry, 13, 543-552.

Clark, I., 1979. Practical Geostatistics, Department of Mineral Resources Engineering, Royal School of Mines, Imperial College of Science and Technology, London, 129pp.

Clark, I., Fritz, P., 1997. Environmental Isotopes In Hydrogeology. Lewis Publishers, CRC Press, Boca Raton - New York, 328pp.

Cossu, R., Muntoni, A., Chiarantini, L., Massacci, G., Serra, P., Scolletta, A., Sterzi, G., 1997. Biogas emissions measurements using static and dynamic flux chambers and infrared method, Proceedings Sardinia 97, sixth International Landfill Symposium, S. Margherita di Pula, Cagliari 13-17 October, CISA.

Doveri, M., Leone, G., Mussi, M., Raco, B., Tifirò, S., 2007. The value of isotopic analyses in monitoring MSW landfills impact on groundwaters. Geoitalia 2007, Sesto Forum Italiano di Scienze della Terra, Rimini 12-14 sett. 2007, Federazione Italiana delle Scienze della Terra: Epitome vol. 2, 2007: 380-381.

Gonfiantini, R., 1983. La composizione isotopica delle precipitazioni. Rend. Soc. It. Min. Petrol., 38: 1175-1187.

Grassi, S., Kolios, N., Mussi, M., Saradeas, A., 1996. Groundwater circulation in the Nea Kessani lowtemperature geothermal field (NE Greece). Geothermics, V. 25 n² 2:231-247.

Hackley, K. C., Liu, C. L., Coleman, D. D., 1996. Environmental isotope characteristics of landfill leachates and gases. Ground water, 34, 5: 827-836.

IAEA, 1981. Stable Isotope Hydrology, Deuterium and Oxygen-18 in the Water Cycle. Interntional Atomic Energy Agency, Vienna, pp. 337.

IAEA, 2007. http://www.iaea.org/programmes/ripc/ih/index.htm

Kanemasu, E.T., Power, W.L., Sij, J.W., 1974. Field chamber measurements of CO2 flux from soil surface. Soil Science, 118,4, 233-237.

Kucera, C., Kirkham, D. R., 1971. Soil respiration studies in tall grass Prairie in Missouri, Ecology, 52, $912-915$.

Parkinson, K.J., 1981. An improved method for measuring soil respiration inthe field, J. Appl. Ecology, 18, 221-228.

Raco, B., Cioni, R., Guidi, M., Scozzari, A., Lelli, M., Lippo, G., 2005. Monitoraggio del biogas diffuso dal suolo da discariche RSU: il caso di Legoli, Peccioli, Pisa. Rifiuti Solidi 2005.

Sichel, H.S., 1966. The estimation of means and associated confidence limits for small samples for lognormal population, Proc. 1966 Symp. South African Institute of Mining and Metallurgy.

Sinclair, A.J., 1974. Selection of threshold values in geochemical data using probability graphs. Journal 
of Geochemical Exploration, 3, 129 - 149.

Sinclair, A.J., 1991. A fundamental approach to threshold estimation in exploration geochemistry: probability plots revisited, Journal of Geochemical Exploration, 41, 1 - 22.

Tonani, F., Miele, G., 1991. Methods for measuring flow of carbon dioxide through soils in volcanic settimg, Napoli '91. International Conference on Active Volcanoes and Risk Mitigation. Napoli, $27 \mathrm{Au}-$ gust-1 September. (abstract).

Trégourès, A., Beneito, A., Berne, P., Gonze, M.A., Sabroux, J.C., Savanne, D., Pokryszka, Z., Tauziède, C., Cellier, P., Laville, P., Milward, R., Arnaud, A., Levy, F., Burkhalter, R., 1999. Comparison of seven methods for measuring methane flux at a municipal solid waste landfill site. Waste Management Research, 17, 453 - 458.

Witkamp, M., 1969. Cycles of temperature and carbon dioxide evolution from litter and soil, Ecology, 50, $922-924$. 